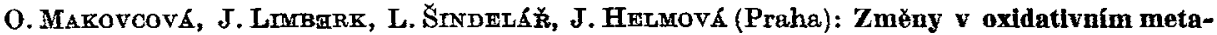
holismu rajěete (Solanum lycopersicum L.) nakaženẻho vírem svinutky bramboru. - Biol. Plant. $17: 113-119,1975$.

Byly sledovány metabolické zmæ̌ny v rajčeti infikovaném virem svinutky bramboru. Přenos byl proveden roubováním nemocného rajčete. $V$ období před srůstem roubu s podnoží jsou prudké výkyvy $v$ intensitè respirace a aktivitách sledovaných enzymů zřejmę součástí obranných reakcí rostliny. $\mathrm{U}$ kořenů pokusných rostlin dochází téměř $\mathrm{k}$ úplné shodě prủbðhu aktivit o-difenoloxidasy a oxidasy kyseliny askorbové s intensitou respirace. U nadzemních částí je zapojen respirační řetězec s kyselinou askorbovou jako terminální oxidasou, zatímeo u kořenủ se úč́astní respirace pravděpodobně řetězce oba, ěímž je dosaženo návaznosti na odbourávání sacharidủ. Intensita glykolysy a pentosového cyklu u kořenủ pokusných rostlin je témǒř stejná. Ze srovnání aktivit dehydrogenasy Glc-6-P a oxidasy kyseliny askorbové vyplývá stejný charakter prùběhu obou těchto křivek, z čehož lze soudit na prítomnost a ěinnost respiračního retězce s oxidasou kyseliny askorbové jako terminální.

\title{
BOOK REVTEW
}

Giess, A. C. (ed.): Photophysiology. Current Topies in Photobiology and Photochemistry. Vol. VIII. Academic Press, New York and London, 1973. 269 S. 22,50 \$.

Die Reihe Photophysiologie bringt seit 1964 in Form von Ubersichtsreferaten neue Kennt. nisse auf dem Gebiet der Interaktion von Licht mit lebenden Organismen und Zellen. Der achte Band dieser Reihe enthält acht Kapitel, wobei die meisten den Pflanzen gewidmet sind. $O$. BJörK MaN fasst im ersten Kapitel unsere Kenntnisse über die Photosynthese der höheren Pflanzen, die photosynthetischen Vorgänge, die verschiedenen Photosynthese-Pfianzentypen und die Photosynthese-Adaptationen zusammen. N. I. BIsHoP analysiert Photosyntheseuntersuchungen in Grünalgen-Mutationen, J. S. Brows behandelt die Trennung des Photosystems I und II mit Hilfe von morphologischen und physikalischen Methoden und G. HIND und R. E. McCARTY berichten über die Aufgabe des Kationenstromes in der Chloroplastenaktivität. In der zweiten Hälfte des Buches werden von D. L. Keister und D. E. FusischMaN dio Stickstoffbindung in photosynthetischen Bakterien besprochen, von D. REGAN die parallelen und nacheinander folgenden Vorgänge im Sehvorgang beim Menschen behandelt, auf die durch Registrierung der durch Licht hervorgerufenen Potentiale gesehlossen wird. Wachstums- und Atmungshemmun. gen durch sichtbares Licht und Licht naher Wellenbereiche sind das Thema des siebenten Kapitels von B. L. EPEL - Photosensitivität verschiedener Organismen und Mechanismus der Einwirkung werden behandelt. Chemische Thematik behandelt R. O. RAHN - die Denaturierung von mit UV-Licht bestrahlter DNS, die Typen der Defekte, deren qualitative und quantitative Bestimmung und Verteilung bzw. Ausmasse. Die einzelnen Kapitel sind sehr übersichtlich und einheitlich gegliedert, illustriert und schliessen mit Literaturverzeichnissen. Der Band enthält kurze Autoren: und Sachregister. Die Beiträge wurden von führenden Wissenschaftlern verfasst, was in einem hohen Niveau resultiert und so das Buch zu einem wertvollen Baustein der photophysiologisehen Literatur macht. 